\title{
REVIEW
}

\section{Daniel J. Harrington, S.J. The Synoptic Gospels Set Free: Preaching without Anti-Judaism}

(Mahway, NJ: Paulist Press, 2009), paperback, xii + 231 pp.

Michael J. Cook, Hebrew Union College-Jewish Institute of Religion

In this compact volume, Jesuit Father and New Testament scholar Daniel Harrington analyzes forty-five Synoptic texts: fifteen each from Matthew, Mark, and Luke. These are keyed to readings from the three-year Sunday Lectionary used in the Roman Catholic Church and mainline Protestant churches. Each series of expositions opens with Harrington's views regarding the Gospel's author and provenance, major themes, and the potential for misreading the text antiJewishly. By demonstrating the Synoptics' rootedness in their first-century Jewish context, and emphasizing Jesus' Jewishness, Harrington aims to free the Synoptics from anti-Jewish misappropriation, particularly in preaching. The book is thus "intended...for the pastor, the parishioner, seminarians and ALL Christians of good will who wish to better understand the Scriptures in their context so that anti-Semitism does not seep in" (back cover). (The Gospel of John is treated in Paulist's 2008 companion volume by Father George Smiga, The Gospel of John Set Free: Preaching without Anti-Judaism.)

Certain key emphases surface repeatedly in the course of Harrington's exegeses: Christianity can be affirmed without denigrating Jews or Judaism; Jesus' fulfillment of Hebrew Biblical passages hardly exhausts their abiding value and integrity ("fulfillment does not require abolition" [p. 85]); and one should avoid negative stereotyping of the Pharisees as legalistic, for Jesus shared a spiritual agenda with these learned teachers (although he was not a Pharisee himself). By these and similar arguments, Harrington aims to help free the Synoptic texts from continuing to contribute to the disastrous effects of their past anti-Jewish applications.

Even apart from his stated goal, Harrington's contribution constitutes a sterling introductory commentary to the Synoptic Gospels as a whole. Among his very best explications are those dealing with the Kingdom of God (pp. 87, 112); the qorban (p. 108); the Transfiguration (p. 117); the poor, generous widow (p. 130); what Harrington (among others) terms Mark's "odd block" Passover unit (pp. 138-139); and the parables of the Good Samaritan (pp. 184-185) and the Prodigal Son (p. 201). Throughout Harrington's presentations, he spotlights Jesus' consistently radical pronouncements as yet remaining within the contours of the variety of contemporaneous Judaisms. Criticisms that Jesus lodged against other Jews, including even the Jerusalem Temple establishment, hardly set him outside Jewish boundaries because so many of his fellow Jews surely felt the same way.

Harrington's volume will be most helpful to readers who will accept what he lays out as his starting assumptions: that all three Synoptists were Jewish by extraction and disposition; that firstcentury Judaism is the suitable and sufficient backdrop for interpreting Synoptic portrayals of Jesus' ministry (Harrington seldom notes Greco-Roman attitudes and biases); and that antiJudaism is not inherent in the Synoptics themselves but is a function of how these Gospels were 
wrongly enlisted throughout later history. Further, whatever seemingly anti-Jewish rhetoric may indeed punctuate these Gospels reflects intra-family or in-house squabbling, along the lines of a kind of Jewish sibling-rivalry.

These premises, fruits of Harrington's long and esteemed career, are undoubtedly reached with care. But within this volume, he does not take sufficient opportunity to justify them vis-à-vis competing positions. The result will be that readers not sharing Harrington's starting assumptions may well have qualms even about the book's title. They may question whether Harrington's analyses do after all genuinely "free" the Synoptic Gospels of their anti-Jewish misapplications.

The net effect of his starting assumptions is to shelter these three Gospels from claims that they themselves foster anti-Judaism. Skeptics may thus argue that the book is really about freeing modern preachers from the Synoptics' actual anti-Judaism, as well as to free Jesus from the Synoptists' actual anti-Jewish recastings of him. To welcome those harboring such doubts would require Harrington to address more fully readily predictable questions, as in the following examples:

A significant proportion of scholars believe that at least one Synoptist (Luke) or possibly two (adding Mark) and, less frequently, all three (perhaps a putative final redactor of Matthew), were actually Gentile by extraction as well as diaspora-based. Accordingly, one can question Harrington's almost exclusive concentration on first-century Judaism of the holy land when the Synoptists themselves could have been reacting to contemporaneous Judaism of the GrecoRoman diaspora where, after all, the vast majority of Christians lived post-70 CE. Indeed, were any of the Synoptists actually writing for such communities of diaspora believers, many of whom were Gentiles? For that matter, was any Synoptist influenced by Gentile anti-Jewish sentiment already native to some diaspora settings (cf. Rom 11:13-32)? In these lights, anti-Jewish wrangling reported in the Synoptics could well reflect circumstances considerably more serious than mere intra-family squabbling.

Presuming Markan priority, as does Harrington, one could argue that Matthew and Luke repeatedly and methodically appear to intensify Markan texts anti-Jewishly. For example, compare Mt 26:59 with Mk 14:55; Mt 23:1-36 with Mk 12:38-40; Mt 27:25 with Mk 15:14-15. Also, one might note Matthew's decision not to retain Mk 12:29a and 12:32-34, and Luke's advanced placement and intensification of Mk 6:1-6a, among a plethora of still other such examples. We then might also conjecture that Mark, even earlier, likewise revised his own sources anti-Jewishly, roughly paralleling what Matthew and Luke later did to material they received from him.

Such questions raise a dilemma: can the completed Synoptics themselves be "set free" from anti-Judaism if quite possibly they already manifested it themselves? While Harrington is surely correct that the Synoptics later on became misapplied anti-Jewishly, such misapplication could also be an exacerbation of anti-Jewish tendencies which characterized these Gospels ab initio. Especially telling, then, is the questionable phraseology on the back cover: to say that later antiJudaism "seeped into" the Synoptic Gospels seems to prejudge that no anti-Judaism could have resided there originally.

Fortunately, all readers, skeptics included, can distill fabulous gems from Harrington's forty-five exegeses. For rarely, elsewhere, does one encounter such precision in resolving challenging passages, all accomplished with an economy of language. Still, while readers will enjoy this book enormously, they might wonder exactly who here is being "set free" from anti-Judaism: the historical Jesus, the Synoptic Gospels, or modern preachers-or perhaps some of these in combination? 